\title{
SEDUÇÃO, ESTUPRO E CASAMENTO NO SÉCULO XVIII: DESCOBRINDO AS MULHERES DA PARAÍBA COLONIAL
}

Luisa Stella de Oliveira Coutinho Silva

Advogada. Doutoranda em História do Direito. Faculdade de Direito da Universidade de Lisboa. Bolsista da CAPES, processo 0718-14-9.

António Pedro Nina Barbas Homem

Professor Catedrático da Faculdade de Direito da Universidade de Lisboa.

\section{Resumo}

Estudar o Direito Colonial implica o uso de uma mentalidade diferente de modo a compreender seu funcionamento já bastante longe da maneira de pensar o Direito atualmente. No período colonial a Igreja Católica era um importante e influente poder junto do Estado e da Inquisição, as três jurisdiçôes existentes no Antigo Regime imprescindíveis ao estudo do direito português e brasileiro dos séculos XVI, XVII e XVIII. Esse poder religioso que emana de uma instituiçáo relacionada às crenças e ao pensamento ideológico permite $o$ acesso às instâncias políticas individuais e coletivas da vida privada e pública das pessoas em sociedade. Dentre a imensidão de artigos de Ordenaçôes, leis, alvarás, regimentos, monitórios e constituiçóes sinodais vamos nos concentrar na análise dois casos ocorridos na Capitania da Paraíba em meados do século XVIII. Ambos tratam de casos de sedução, rapto e estupro, conceitos que precisam ser entendidos em comparação ao padrão e ato esperado, desejado e recomendado a todas as mulheres como modelo: o casamento.

\section{Palavras-chave}

Mulheres; Brasil Colonial; Casamento; Estupro.

\section{Abstract}

The study of the Colonial Law in order to understand its operation requires a different way of thinking, quite far from the way the Law works nowadays. In the colonial period, during the Antigo Regime, we had three coexisting jurisdictions, the Catholic Chur$\mathrm{ch}$, the State and the Inquisition. This outset is essential to the study of Portuguese and Brazilian Law in the 16th, 17th and 18th centuries. The religious powers that came from 
institutions associated to the beliefs and ideological thinking allowed the access to individual and collective political bodies of private and public life of people in society. Among the immensity of articles from the ordinances, laws, alvarás, regulations, monitórios and synodical constitutions we will focus on analyzing two cases occurred in captaincy of Paraíba in the middle of the 18th century. Both cases deal with seduction, kidnapping and rape, concepts that need to be understood in comparison with the standard and the expected act, desired and recommended to all women as a model: the marriage.

\section{Key words}

Women; Colonial Brazil; Marriage; Rape.

\section{Introdução}

Estudar o Direito Colonial importa numa mentalidade diferente para compreender seu funcionamento já bastante longe da maneira de pensar o Direito atualmente. Nesse momento histórico, a Igreja Católica era um importante e influente poder junto do Estado e da Inquisição, as três jurisdições existentes no Antigo regime imprescindíveis ao estudo do direito português e brasileiro dos séculos XVI, XVII e XVIII. Esse poder que emana de uma instituição relacionada às crenças e ao pensamento ideológico permite o acesso às instâncias políticas individuais e coletivas da vida privada e pública das pessoas em sociedade.

Quando olhamos para o passado, essa visão nublada de hoje em dia repercute também quando queremos entender as nossas origens, porque para além de vivermos numa organização política extremamente diferente dos modelos antigos, possuímos a marca desse mesmo passado no nosso inconsciente, ambiente, visões, ideologias - seja lá que corrente filosófico-psicológica adotemos. O fato é que não nos podemos afastar por demais de nós mesmos quando queremos entender o que se passou.

Os mesmos olhos que veem hoje desigualdade, fome, crise, biotecnologia, carros, elevadores, mães mortas, homens negros acorrentados a postes, estupros, droga, cinema, eutanásia, clonagem, protestos, mídia e a perda da capacidade crítica, socialismo, colonização... são os mesmos olhos que olham para as fontes em busca de uma explicação, numa verdadeira (não sabemos se) viagem ou luta.

Por esta razão os olhares críticos são tão especiais à História, e aqui dizemos que também à História do Direito. Os estudos coloniais podem nos ajudar a ver que toda essa produção arquivística na qual nos fiamos para produzir conhecimento hoje foi produzida sob a inquestionável dominação e subordinação do outro, visto como inferior. Nessa colonização, o Direito nem sempre foi entendido rapidamente da maneira que deveria ser pressuposto por uma metrópole - por isso a Tradução Cultural do Direito (Cultural 
Translation of Law) leva-nos a perceber as nuances de culturas diferentes na construção de um Direito misturado por vários sistemas jurídicos e não só a pura deglutição de novas ordens sobre uma tabula rasa. E por (enquanto) fim, a feminist jurisprudence nos preparou para perceber que as fontes e as instituiçóes podem estar permeadas de perspectivas que também assumem a superposição especificamente de um gênero sobre o outro e, indo mais longe, da violência que essa superposição possa ser por obrigar a heteronormatividade (e as consequências de pertencer a um gênero ou a um sexo) (BUTLER, 2010; MEADOW, 2010).

Essas foram as inquietaçóes que nos levaram até aqui a apresentar um olhar sob um território colonizado e um período específico. Interessa-nos por agora as condiçóes coloniais para a construção de gênero durante a colonização da Paraíba, uma das primeiras capitanias criadas e povoadas pelos portugueses desde o final do século XVI. Sabemos que a metrópole importou um sistema jurídico próprio (dela) e distante da realidade que já existia na colônia e longe da eficácia pretendida para a expansão ultramarina portuguesa nesses anos. A realidade portuguesa era diferente da indígena, da africana e da realidade dos próprios portugueses que vieram para a colônia nesses primórdios da colonização. E nas geraçôes que se seguiram foi-se criando cada vez mais distância da lusa pátria e um sentimento de pertença a algo que não era nem de aqui, nem de lá - a melancolia que chega nos trópicos, como bem diz Scliar (2003).

Por isso, vamos nos concentrar não num modelo da casa grande e senzala, talvez já desatualizado, mas não ousamos continuar a desdizer-lhe por sua importância basilar nos estudos da área. Queremos outra alavanca que possa tocar várias classes, vários gêneros e vários desvios. Iniciaremos por investigar o desenvolvimento do direito e o estabelecimento dos conceitos relacionados ao casamento por ser o instituto essencial que envolvia as mulheres do Antigo Regime. Por fim, infelizmente de forma redutiva aqui, mergulhados na imensidão de artigos de Ordenaçóes, leis, alvarás, regimentos, monitórios e constituiçóes sinodais vamos nos concentrar na análise de dois casos ocorridos na Capitania da Paraíba em meados do século XVIII. Ambos tratam de casos de sedução, rapto e estupro, conceitos que precisam ser entendidos em comparação ao padrão e ato esperado, desejado e recomendado a todas as mulheres como modelo: esse tal matrimônio. Ressalvamos, entretanto, a falta, por enquanto, de referencias as posiçóes da doutrina da época, inclusivamente da doutrina canônica.

\section{Panorama Jurídico Luso-Brasileiro Acerca da Condição da Mulher na So- ciedade}

O casamento era o grande regulador da vida feminina - a vida jurídica das mulheres dos séculos XVI, XVII e XVIII norteava-se pelo seu estabelecimento, para não citar 
outros séculos por enquanto. A Igreja havia tomado para si, em geral, muito da legislação e jurisdição em matéria de casamento (CAETANO, 2000), principalmente sua celebração e puniçôes, afastando o Estado de tais disposiçôes, com remissōes subsidiárias ao direito romano.

A doutrina do casamento baseava-se, inicialmente, no mero contrato consensual, que era a doutrina romana do affectio maritalis e do consenso (MONCADA, 1948). Portanto, mesmo antes do cristianismo, o casamento era entendido como um contrato e assim dependia da vontade das partes. Herculano (1866) também mostra que entre os romanos o casamento era um contrato essencialmente civil. Os primeiros cristãos conciliaram a existência do sacramento com o contrato civil, aceitando ambas as coisas, subsistindo mesmo depois do cristianismo ser adotado como religião oficial do Estado. $\mathrm{O}$ mútuo consenso bastava, como está escrito no Código Teodosiano, lei 428, para caracterizar o ato e o código de Justiniano ampliou a doutrina aos consórcio de todas as pessoas livres. Desse modo, como o casamento era um contrato, só dependia do consentimento. Ademais, o próprio Justiniano modificou o código em lei posterior: bastava qualquer testemunha dizer que os cônjuges viviam como marido e mulher para provar a relação.

Em geral, havia diferentes maneiras para fazer prova do contrato entre os romanos segundo a classe social: a nobreza fazia contratos antenupciais (prova do consórcio); a classe média ia à Igreja, não para o sacramento, mas para declarar que se casavam ao defensor; a plebe casava sem qualquer intervenção de autoridade, bastava o simples acordo vocal. Essas regras e costumes vigoraram até 911 com o imperador Leão VI, que ordenou que o casamento tivesse a santificação da Igreja para ter validade.

Na época da vigência do Código Visigótico durante a regência da monarquia leonesa e no início de Portugal, não houve alteraçóes quanto a tradição jurídica romana. $\mathrm{O}$ código não alterou a doutrina romana dos consórcios contraídos sem sacramento entre plebeus, servos ou classes elevadas, como observa Herculano (1866). Ao remontar ao direito visigótico, que deixou importantíssima herança no direito português, Gilissen (2008) percebe que as uniões não deixavam de ser consideradas como casamento se não tivessem a desponsatio ou a bênção. Tudo indica, nessa lógica, que esse tipo de casamento se dava na falta de acordo do pretendente com a família da futura esposa.

A discussão sobre o acordo das partes versus a solenidade do ato permaneceu por toda a Idade Média Portuguesa (HERCULANO, 1866). Os papas se pronunciaram sobre o assunto na Europa, como é o caso de Nicolau I, que dizia que quando as circunstâncias obstassem à celebração do casamento religioso, os fieis podiam contrair matrimônio civil. Já Adriano II defendia que se o matrimônio fosse contraído em conformidade com as leis, era válido; Alexandre III ordenou que se um marido voltasse à sua primeira mulher e considerasse esse casamento válido mesmo não tendo havido coabitação, mas palavras de presente, o casamento era válido; Inocêncio III dizia que o matrimônio se contraía por 
legítimo consenso, mas pelo que toca à Igreja eram necessárias palavras que exprimissem o consentimento presente e Gregório IX determinou que os casamentos contraídos sem solenidades nas Igrejas fossem válidos. Portanto, o assunto foi bastante repetido no seio da Igreja Católica, e mesmo o grande expoente do Direito Canônico, Graciano, defendeu que era casamento válido, porém não legítimo, aqueles que desprezavam as solenidades e só consideravam o amor a uma mulher.

A Igreja legitimou, portanto, em tempos primevos, tal prática. Daí nos séculos XII e XIII haver os casamentos de bênção e os de pública fama. Ainda havia o casamento de juras entre aqueles em que o mútuo consentimento era firmado com juramento perante qualquer ministro de culto (HERCULANO, 1866).

Em Portugal, o debate tocava a própria discussão acerca dos limites das jurisdiçóes. O rei Afonso III publicou lei a defender que todos os casamentos se faziam por palavras da Santa Igreja, contanto que fossem realizados sem pecado. E todo casamento podia ser provado, seja a ocultas ou de forma pública, tendo os contraentes idade legítima. As palavras de presente, então, eram conhecidas como Ego te recipio in meam, et ego te in meum (recebo-te como minha, recebo-te por meu). O rei D. Dinis, em lei de 15 de maio de 1311, defendeu que o costume consagrava a doutrina de que vivendo homem e mulher por 7 anos contínuos, coabitando na mesma casa como cônjuges, e nessa reputação, o casamento era indissolúvel. Diz a lei:

Como se prova o casamento per fama

Costume he desy he dereito que se huum homem viuy com hua molher $\mathrm{E}$ mantem casa ambos desuum per sete anos continoadamente chamandose ambos marido E molher se fazem anbos conpras ou vendas ou emprazamentos./ E se poserem em elles nos stormentos ou cartas que fezerem marido E molher E em-na auizijindade os ouuerem por marido E molher nom podem nenhum delles negar o casamento $\mathrm{E}$ aue-llos-am por marido E molher ajnda que nom sejom casados em façe da egreja. (DUARTE, 1988, p. 216.)

Até aqui, então, mantinha-se a natureza de contrato, de consórcio/jurisprudência e costume romano, mantendo penas espirituais contra os casamentos clandestinos, mas não os tornando nulos.

A partir de uma lei de D. Manuel I, de 14 de julho de 1499, o casamento clandestino passou a ser punido com confisco e degredo, exceto caso tivesse acontecido com permissão dos pais e mães dos contraentes, decorrendo apenas as penas canônicas. No caso, manteve-se o poder paternal e o casamento clandestino continuou a existir. Diz a lei que

(...) considerando o Senhor Rei D. Manuel I os justos respeitos e motivos, porque a Sancta Igreja prohibia os matrimonios clandestinos, e porque 
as penas postas por Direito canonico nom som aly temidas quanto com rrezam deuem seer, (...) porque aquelles que o temor de deos nom rrefrea de mallfazer a pena tenporall os deue do pecado afastar; determina, que pessoa alguma de qualquer estado e condiçãoo que seja não case com senão publicamente, e em face da Igreja, precedendo os pregoens, que em Direito se chamáo bainos, que se devem fazer segundo disposição de Direito Canonico nas Igrejas d'onde são fregueses aquelles, que querem casar; ou com authoridade do Prelado, que para isso tenha poder. (FIGUEIREDO, 1790, p. 150.)

Também não se há de esquecer, antes de chegarmos às Ordenaçóes Manuelinas, dos Sínodos portugueses e as Constituiçóes Sinodais, importantes para a incorporação, no futuro, das determinaçóes dos Concílios. Nesse momento cronológico, citamos as Constituiçóes de D. Diogo de Sousa, de 1505. Importa, agora, referir A Constituição XL que tratava especialmente "Acerca dos matrimónios clandestinos". (GUIMARÁES, 2001.)

Com as Ordenaçóes Manuelinas, o casamento chamado até aqui de clandestino continua a ser aceite, sendo feitos nos seguintes modos:

Livro 2, Título XLVII (...) 1. E por quanto segundo fórma de Nossas Ordenaçóes, quando algumas molheres sam casadas com alguns homens por palavras de presente, e ouveram com eles copula carnal, sam meeiras em seus bens e fazenda, Declaramos que esto aja lugar, quando o casamento foi aa porta da Igreja, ou por licença do Prelado fóra da Igreja, e bem assi quando ambos estavam em voz e fama de marido e molher, posto que o casamento nom fosse aa porta da Igreja, ou por licença do Prelado; porque posto que elles queiram provar, e provem que sam recebidos por palavras de presente, e que ouveram copula, se nom provarem que foram recebidos aa porta da Igreja, ou po licença do Prelado como dito he, ou nom provando como estam em pubrica voz, e fama de marido e molher, e em casa theuda e mantheuda, ou em casa de seu pay, ou em outra casa onde estever, nom seram meeiras; e quando provar que foram recebidos, posto que seja clandestinamente, provando como esteveram em voz, entonce seram também meeiras. 2. E porem nom Tolhemos para que prova de serem meeiros, que o nom possam provar, quando esteverem por tanto tempo em casa theuda e mantheuda, em pubrica voz e fama de marido e molher, que segundo Dereito abasta pera presumir matrimónio pera sucessam, e pera seer meeira, posto que se nom provem as palavras de presente, segundo for achado por Dereito que abasta. (Ordenaçóes Manuelinas, 2006, p. 237 e 238.)

Entretanto esse contrato sem tantas formalidades eclesiásticas, em comparação com as diretrizes futuras, barra na representação do consentimento, que é feita pelo pai, mãe, avô ou outra pessoa sob a qual esteja em poder, como consta no Livro 5, título XXXII das 
mesmas Ordenações. Nesse caso, a mulher era jovem, de até 25 anos, e virgem, ou uma viúva honesta.

Em 1538 foram publicadas as Constituiçôes Sinodais do cardeal-infante D. Henrique. Nelas, consta na Constituição V o título sobre "aqueles que casam fingidamente" (GUIMARÁES, 2001). A Constituição I disserta sobre "Que todos aqueles que quiserem casar primeiro que sejam recebidos, sejam apregoados na Igreja e dos que fazem prometimentos e dos que casam por palavras de presente e de que idade há-de-ser." (GUIMARÃES, 2001, p. 147).

Até aqui, antes do Concílio de Trento, que vai marcar intensamente o assunto, podemos dizer que na Idade Média havia três tipos de casamentos (MONCADA, 1948): casamento de bênção, o casamento de pública fama e o casamento a furto ou de juras. Os três diferenciavam-se pela solenidade com que eram celebrados: o primeiro era o verdadeiro casamento religioso e solene, depois valorizado pelo Concílio de Trento, com a intervenção do sacerdote. Estava impregnado de todas as formalidades, enquanto as duas outras modalidades eram as clandestinas e se faziam provar de outras formas.

Os casamentos de pública fama e a furto eram celebrados sem formalidades, geralmente nas casas dos pais dos noivos ou em qualquer outro lugar. Nada impedia que os nubentes fossem depois em busca da bênção da Igreja. O professor Cabral de Moncada (1948) insiste em que, os efeitos dos três tipos de casamento são indiferentes, a diferença se encontra na forma de celebração dos mesmos e a consequente forma de prová-los.

O casamento a furto é semelhante ao raptus romano, que era simulado em todos os casamentos romanos feitos pela confarreatio. Persistiu mesmo no Portugal medieval do século XIII e XIV, como um ideal de cavalheiro, que era fazer do casamento uma iniciativa desse e não da família da mulher. Sobre o casamento de juras, no direito matrimonial pré-tridentino nem a bênção nem outras solenidades eram exigidas para que o casamento fosse considerado válido, sendo necessário apenas o mútuo consenso dos noivos e duas testemunhas (MÊREA, 1952).

Mas chegamos ao Concílio de Trento. Ocorrido entre 1545 e 1563 - momento crucial para a Igreja Católica, pois eram anos difíceis por causa da Reforma Protestante que colocava em risco a doutrina católica -, estabeleceu diretrizes que foram aplicadas em todo o mundo católico, principalmente na matéria sobre o casamento. O que preocupava a mentalidade católica da época era o casamento clandestino. Convinha ou não anular os casamentos clandestinos? O matrimônio cristão devia se reputar sempre sacramento? Ou era apenas aquele segundo os ritos? Nos vários anos do encontro, tivemos muitas posiçóes: o Bispo de Modena e o Bispo de Almeria defendiam um decreto de anulação dos consórcios clandestinos; contrário, o Bispo d'Ipres pensava o matrimônio como um contrato de direito natural e perpétuo; já o Bispo de Salamanca era de opinião de que o 
casamento, como é um contrato civil, deveria estar sob poder temporal se fosse entre náo cristãos e caso fosse entre cristãos, a matéria precisava do sacramento e poder eclesiástico. Estas são algumas posições para ilustrar as divergências que organiza Herculano (1866).

Portugal participou ativamente do Concílio enviando representantes e pondo em prática as disposiçóes desse grande encontro anti-reforma, principalmente através do alvará de 12 de setembro de 1564 (CASTRO, 1944). Os seus representantes no Concílio foram: Frei Baltazar Limpo, da ordem do Carmo, bispo do Porto; padre Frei Jorge de Santiago, da ordem dos Pregadores; padre Frei Jerônimo d'Azambuja, também da ordem dos Pregadores; padre Frei Gaspar dos Reis, da ordem dos Pregadores, entre outros prelados que enviaram seus mandados (no pontificado do papa Paulo III). Logo que o bispo do Porto retornou, D. Joáo III mandou que o mesmo se reunisse com letrados para estudarem maneiras de pôr em prática os resultados do Concílio.

Mas, afinal, o que foi por fim estabelecido em Trento? Pelo primeiro cânon o Concílio anatemizou os que disserem que o matrimônio não é um dos sete sacramentos da lei evangélica e instituído por Cristo, mas inventado na Igreja pelos homens, e que não confere a graça divina. $\mathrm{O}$ novo rito do casamento passou a necessitar de três denúncias feitas pelos párocos dos contraentes, em três dias santos consecutivos, e depois se precederia a celebração do casamento em face da Igreja, caso não houvesse impedimentos. $\mathrm{O}$ padre tinha que interrogar os nubentes e ouvir o mútuo consentimento, quando diria: uno-vos em matrimônio no nome do padre, do filho e do espírito santo. Tal disposição deveria vigorar 30 dias depois da publicação em cada paróquia. Trento, portanto, queria acabar com a clandestinidade; anular os contratos sem sacramento, tomando para si uma parte da autoridade secular.

O que historiadores como Herculano (1866) defenderam é que o matrimônio passou a ser confundido com o sacramento do matrimônio. Cristo, entretanto, institui um sacramento e não um contrato e o matrimônio existia antes da lei evangélica. Ademais, o Concílio não definiu as diferenças entre matrimônio e contrato. A escolástica confundia as duas ideias, o que dominava o ensino da teologia.

O Decreto de Tametsi da Sessão XXIV do Concílio Tridentino inovou as formas de contrair matrimónio solene: quanto às denunciaçôes, ao poder do Bispo em dispensá-las e criou a obrigatoriedade da presença do pároco mais duas ou três testemunhas. Esse decreto também tratou, no capítulo $\mathrm{V}$, das penas a aplicar aos raptores de mulheres pela força

Mas nem por isso os casamentos civis deixaram de existir. Herculano (1866) diz que as doutrinas são imutáveis e que casamentos civis continuaram a ser válidos. Depois do Concílio, a mesma disposição das Ordenações Manuelinas continuaram em vigor e foram confirmadas em uma reedição de 1565. Entretanto, as disposiçóes de Trento estavam em vigor desde 1564 pelo Alvará do rei D. João III de 12 de setembro, que publicou 
e recomendou a observância do Sagrado Concílio Tridentino em todos os domínios da Monarquia Portuguesa, cuja cópia podemos ler nos Aditamentos do Código Filipino, Livro II (2004).

Em 1564 também veio a tona o Decreto sobre o matrimónio de Frei Bartolomeu dos Mártires, pelo que foi dito que nas denunciaçóes, banhos ou proclamas o pároco deveria anunciar o casamento durante três domingos seguidos na Igreja. Impôs também a celebração do matrimônio dentro do templo (GUIMARÁES, 2001).

Entretanto, as confusóes hermenêuticas persistiram acerca da abrangência de cada jurisdição e as novas diretrizes tridentinas. Por isso, foi necessária a ajuda do braço secular à Igreja, o que segundo Herculano (1866) não envolvia a anulação das leis civis diante do direito canônico embora muitos outros assim defendessem. Por isso, na provisão de 2 de março de 1568, que pode ser encontrada na parte II, título II, Lei XII de LEAO (1569, p. 81), o rei faz referência às dúvidas surgidas acerca do cumprimento de alguns decretos do Concílio Tridentino e reforça o seu desejo de vê-los executados em Portugal, "de modo que nosso Senhor seja servido e a jurisdição eclesiástica seja guardada e favorecida" (LEAO, 1569, p. 81v), oferecendo, portanto, a ajuda secular. Inclusive, nesta provisão são declarados os crimes mixti fori: adultério, barregania, concubinato, alcoviteiros e daqueles que consentem que as mulheres façam mal uso de seus corpos, incestos, feiticeiros, benzedeiros, sacrilégio, blasfêmia, perjúrios, onzenaria, simonia.

As Ordenaçôes Filipinas mantiveram as disposiçóes das Manuelinas acerca do reconhecimento do casamento. No livro IV, título XLVI, parágrafo $2^{\circ}$, é dito que

(...) quando o marido e mulher forem casados, por palavras de presente á porta da Igreja, ou por licença do Prelado fora della, havendo cópula carnal, serão meeiros em seus bens e fazenda. E posto que elles queiram provar, e provem que foram recebidos por palavras de presente, e que tiveram cópula, se não provarem que foram recebidos á porta da Igreja ou fóra della, com licença do Prelado, não serão meeiros. 2. Outrossim serão meeiros, provando que estiveram em casa teuda e manteuda, ou em casa de seu pai, ou em outra, em publica voz e fama de marido e mulher por tanto tempo, que, segundo Direito, baste para presumir Matrimonio entre elles, posto se se não provem as palavras de presente. (Ordenaçôes Filipinas, p. 832).

Tal dispositivo trouxe grande confusão à interpretação da aplicação das diretrizes tridentinas em Portugal. Herculano (1866), em resposta ao visconde, discute bastante o porquê desse parágrafo $2^{\circ}$ existir após Trento e após o Decreto de Tametsi. De fato, acreditamos serem necessárias mais fontes documentais e mais fatos para atestar a repercussão da redação posta nas Ordenaçóes Filipinas acerca do matrimônio sem as formalidades de Tametsi. Mas podemos seguir em frente com uma prova documental mais prática, 
um assento da Casa da Suplicação. No assento de 1 de julho de 1631 o tribunal dispóe sobre uma "pena imposta pela Ordenação aos que casão com mulheres menores de vinte e cinco anos sem autoridade de seos Pais, ou Tutores, tem lugar, ou os casamentos sejão clandestinos, ou feitos com licença do Ordinario" - ou seja, o livro 5. ${ }^{\circ}$, título XXII, procede, náo só nos que casam clandestinamente, mas ainda com licença do Ordinário. $\mathrm{O}$ assento punia o matrimônio de menores de 25 anos sem autorização, mas não invalidava a relação matrimonial. Os casamentos clandestinos continuavam a existir, então. (COLLECÇÃO CHRONOLOGICA DOS ASSENTOS DAS CASAS DA SUPPLICAÇÃO E DO CIVEL, 1791, P. 61).

Tanto que nas Cortes de 1641 os procuradores do povo pediram breve sobre o casamento clandestino, posto que não eram suficiente as disposições do Concílio, e na prática continuava o hábito de castigar sem anular. D. João IV publicou Carta de Lei de 13 novembro de 1651, com providências contra matrimônios clandestinos, em que declara que todos de

(...) qualquer qualidade e condição que seja, que, da publicação desta em diante contrahir matrimonio, que a Igreja declarar por clandestino, pelo mesmo caso, elles e os que nelle concorrerem e intervierem, e os que no tal matrimonio forem testemunhas, incorrerão incorrerão no perdimento de todos os seus bens, que seráo aplicados a meu Fisco Real e serão desterrados para uma Conquista destes Reinos, nos quaes não entrarão com pena de morte; e não havendo herdado a herança de seus pais, ao tempo que o matrimonio clandestino for contrahido, o pai e mãe o possam desherdar; e qualquer do povo possa accosar este crime, depois de declarado o tal matrimonio por clandestino no Juizo Ecclesiastico. (...) (SILVA, J., 1856, p. 88.)

Herculano (1866) ironiza com os requisitos de Trento: bastava duas testemunhas e autoridade legítima para não ser clandestino; mas se o matrimônio fosse celebrado por autoridade incompetente na frente de cem pessoas seria clandestino.

No Brasil, de extrema importância para a aplicação do Concílio foram as Constituiçôes Primeiras do Arcebispado da Baía, feitas por D. Sebastião Monteiro da Vide, em 1707, baseadas nas Constituiçóes Sinodais de Lisboa. Compunham um livro de treze constituiçóes que adaptavam as normas tridentinas ao contexto brasileiro, embora adotassem a organização e temática utilizada em Braga por D. Sebastião de Matos e Noronha. As normas ditavam acerca do sacramento do matrimônio, da sua instituição e matéria, seus fins e efeitos. Grande novidade foi a disciplina dos matrimônios dos escravos (VIDE, 1853).

Outra circunstância que dificultava caracterização do perfeito matrimônio no mundo luso eram os desvios provocados pelos estupros através de rapto ou sedução. O tema já 
preocupava o direito português desde o século XIV. A lei já citada de D. Dinis de 15 de maio de 1311 fazia uma referência importantes de como as mulheres devem reclamar dos estupros sofridos, importante para a análise a seguir da concepção jurídica da violência contra as mulheres:

Como se entende a molher forçada pollo costume

Estabellecudo he que se allgua molher se chamar forçada dezendo que allguum homem Jouue com ella per força em algum hermo E ho quer prouar pollo costume pera auer pena aquell qu’a forçou conuem que uenha braadando E fazendo synaes de forcada conuem a saber carpindo ou chorando. E fazendo queixume aos que achar dezendo que a forçou foaão nomeando-o per nome se o souber E se o nom souber deue dezer os sygnaes dele. E tanto que chegar aa villa ou a poborado hu ouuver Juiz deue d'hir dereitamente logo em ese dia ante que entre em casa nehua sem ditijimento ao Juiz E deue-lhe de dezer E querellar per que guisa a forçarom E quem E o lugar. E outrosy de dezer deue aaquelles que achou pollo camjnho a que fez queixume. E asy prouara a força pollo costume. (DUARTE, 1988, p. 215.)

A perda da virgindade tornava a mulher que possuísse um dote razoável perdida para um futuro brilhante na sociedade, dentro do casamento. A perda da virgindade deixava as mulheres com possibilidades reduzidas para realização de um bom negócio no mercado casamenteiro, tudo estava perdido.

A lei geral do Reino, tem dois artigos muito importantes no disciplina do estupro. O livro V, título XXIII, diz

Do que dorme com mulher virgem, ou viuva honesta per sua vontade.

Mandamos, que o homem, que dormir com mulher virgem per sua vontade, case com ella, se ella quizer, e se fôr convinhavel, e de condição para com ella casar. E não casando, ou não querendo ella casar com elle, seja condenado para casamento della na quantia, que fôr arbitrada pelo Julgador, segundo a sua qualidade, fazenda, e condição de seu pai. E se não tiver bens por onde pague, se fôr Fidalgo, ou de qualidade, que não deva ser açoutado, será degradado para Africa até nossa mercê. E se for pessoa em que caibão açoutes, seja açoutado com baraço e pregão pela Villa e degradado para Africa ate a nossa mercê. E postoque lhe esta pena seja dada por não ter bens, se depois em vida della, elle houver alguns, será obrigado a pagar ametade da dita condemnação sómente. Porém, sendo preso pela dita razão, e pondo caução de ouro, ou prata, ou dinheiro em Juizo, que razoadamente possa bastar, segundo a qualidade das pessoas, á virgindade e satisfação de seu casamento, seja solto, e siga o feito pessoalmete, como se andasse per carta de Seguro. E sendo condonado per sentença final, seja satisfeita essa mulher de sua virgindade por a caução: 
e não bastando para a condenação e custas, pague-se pelos bens do Juiz, que tão pequena caução tomou.

1. E sendo dado querela obrigatoria de algum homem, que per força corrompeo mulher de sua virgindade, responderá preso, até o feito ser findo e desembargado. E quando achado fôr, que foi querelado maliciosamente, seja-lhe satisfeito segundo for direito. Porém, se abertas e publicadas as inquiriçóes, for achado, que a virgindade foi corrompida por vontade della, sem outra força alguma, pondo em Juizo caução idônea de ouro, ou prata, ou dinheiro, segundo acima temos dito; seja solto, e siga pessoalmente o feito, até ser findo.

2. Porém mandamos, que as ditas mulheres, assi corrompidas sem outra força, demandem suas virgindades e satisfação até hum anno, contando do dia, que deixarem de ter affeiçáo com ellas, e passado o dito anno, não possão mais demandar suas virgindades e satisfação dellas, salvo per via de restituição, se forem menores de vinte cinco annos, ou tendo justo impedimento, por onde no dito tempo náo podessem demandar.

3. E tudo isto, que dito he em este titulo, haverá lugar em qualquer homem, que dormir com mulher viuva, que honestamente viver, que não passar de vinte e cinco annos, stando em poder de seu pai, ou avô da parte do pai. (Ordenações Filipinas, p. 1172)

As preocupaçóes da lei são práticas. Sem virgindade, o negócio do casamento estava arruinado. Como soluçáo, era postas duas opçóes: ou o casamento entre ambos que realizaram o ato que desvirtuou a moça ou a compensação financeira pelo estrago feito. $\mathrm{O}$ casamento era a chave, a tal alavanca que já chamamos aqui para resolver todos os problemas. O livro V, título XVIII, diz

Do que dorme per força com qualquer mulher, ou trava della, ou a leva per sua vontade.

Todo homem, de qualquer stado e condição que seja, que forçosamente dormir com qualquer mulher postoque ganhe dinheiro per seu corpo, ou seja scrava, morra por ello. Porém, quando fôr com mulher, que ganhe dinheiro per seu corpo, ou com scrava, não se fará execução, até nol-o fazerem saber, e per nosso mandado. E nessa mesma pena haverá qualquer pessoa, que para a dita força der ajuda, favor ou conselho.

1. E postoque o forçador depois do maleficio feito case com a mulher forçada, e ainda que o casamento seja feito per vontade della, não será relevado da dita pena, mas morrerá, assi como se com ella não houvesse casado. E toda esta Lei entendemos em aquellas, que verdadeiramente forem forçadas, sem darem ao feito algum consentimento voluntario, aindaque depois do feito consummado consintão nelle, ou dêm qualquer aprazimento: porque tal consentimento, dado depois do feito, não relevará o forçador em maneira alguma da dita pena. 
2. E se algum homem travar de alguma mulher, que for per a rua, ou per outra parte, náo sendo para dormir com ella, sómente por assi della travar, seja preso, e até trinta dias na cadea, e pague mil reis para o Meirinho, ou Alcaide, ou outra pessoa, que o accusar. Porém, se além de travar della, trabalhar para dormir com ella, haverá a mais pena, que merecer, segundo disposição de Direito.

3. E o homem, que induzir alguma mulher virgem, ou honesta, que não seja casada, per dádivas, afagos, ou promettimentos, e a tirar e levar fora da caza de seu pai, mai, Tutor, Curador, senhor, ou outra pessoa, sob cuja governança, ou guarda stiver, ou de qualquer outro lugar, onde andar, ou stiver per licença, mandado, ou consentimento de cada hum dos sobreditos, ou ella assi enganada, e induzida se for a certo lugar, donde a assi levar, e fugir com ella, sem fazer outra verdadeira força a ella, ou aos sobreditos, colevador for fidalgo, ou pessoa posta em Dignidade, ou Honra grande, e o pai da moça for pessoa plebea, e de baixa maneira, ou Official, assi como Alfaiate, Capateiro, ou outro semelhante, não igual em condição, nem stado, nem linhagem ao levador, o levador será riscado de nossos livros, e perderá qualquer tença graciosa, ou em sua vida, que de Nós tiver, e será degradado para África até nossa mercê. (Ordenações Filipinas, p. 1168).

A suposta proteção aqui é clara: mulher protegida é a que vive honestamente e não se prostitui. A pena de morra por ello, discutida na doutrina, pode ser, segundo Vanguerve Cabral (1729) e Almeida (ORDENAÇÓES FILIPINAS, LIVRO V, 2004, p. 1170), uma morte que dependia do arbítrio do julgador conforme o excesso e qualidades com que o crime havia sido cometido. Não havendo expressão positiva da morte natural, a morte imediata, morra por ello podia significar a morte civil, que incluía, além da perda dos bens, o degredo ou as galés.

Ainda no Livro 5, título CXXXIV, p. $2^{\circ}$ são organizadas a matéria do procedimento, da forma de reclamação da vítima de estupro:

(...) 2. E bem assi, se em algum lugar ermo algum fosse ferido, ou espancado, ou alguma mulher fosse corrupta de sua virgindade per força, de noite, ou de dia, e o dito ferido, ou espancado, ou corrupta bradasse logo no dito ermo: foão me fez isto; mostrando logo as feridas, nodoas, ou signal de corrompimento de sua virgindade, e sendo aquelle foão, de que bradava, que lhe o dito mal fizera, amostrado pelo que assi brada, e visto por algumas pessoas no dito lugar, fica o dito maleficio provado. (...) (2004, p. 1311).

Quanto menos mostrasse que aproveitara o ato, que não sentira prazer, mais provado estava o seu não consentimento nesse ato. Náo bastava ser estuprada, o Direito exigência brados e as marcas do corrompimento da virgindade. O parágrafo é específico para 
mulheres que perdiam a virgindade, o que mostra o que era importante de se fazer na ocorrência do estupro.

A lei de 19 de junho de 1775 foi motivada pela excesso de escândalos de homens que se abandonavam a uma vida depravada, e que vindos cheios de malícias e libertinagem dedicavam-se a corromper o espírito das filhas famílias sucessoras e bem dotadas sob promessas de casamento, muitas vezes abusando da amizade e do parentesco. Nesse contexto as promessas de casamento eram, segundo a lei, uma arma forte para vencer "hum sexo fragil" (Aditamentos ao livro IV, OF, p. 1050). O rei ordena

Incursas no crime de rapto por sedução todas as pessoas, contra as quaes se provar, que alliciarão, solicitarão, e corromperão as filhas alheias, que vivem com boa, e honesta educação em casa de seus pai, parentes, e Tutores, ou Curadores: ou seja sómente por fim libidinoso; ou para conseguirem por este illicito meio hum casamento que não conseguiriáo pelos da razáo e da decencia. (Aditamentos ao livro IV, OF, p. 1050 e 1051.)

A pena condenatória era de 10 anos de degredo para as galés e se fossem nobres, mais 10 anos para Angola.

Em 6 de outubro de 1784 outra lei foi publicada acerca dos esponsais. Esta regulava a solenidade dos esponsais e providenciava acerca das querelas de estupro. Na motivaçáo da lei, a rainha D. Maria adverte para os prejuízos dos bons costumes e o insucesso do matrimônio em Portugal trazidos pela não observância dos ditames do Concílio e da lei de 13 de novembro de 1651 . Sendo assim, ela ordena que:

(...) nenhuma pessoa de qualquer qualidade, e condição que seja, possa contrahir Esponsaes sem ser por escritura pública, lavrada por Tabellião, e assignada pelos contrahentes, e pelos pais de cada hum delles; e na falta dos Pais, pelos seus respectivos Tutores, ou Curadores, e por duas Testemunhas ao menos; e que náo produzão effeito algum quaisquer promessas, pactos, ou convençôes Esponsalicias, que não forem contrahidas por esta fórma (...). (SILVA, A., 1828, p. 361)

Ademais, até os 25 anos permanece a necessidade de autorização dos pais para contrair esponsais. Essa mesma lei também traz disciplina acerca do crime de estupro, em respeito ao consentimento da vítima e a relaçáo com sua idade. Sendo maior de 17 anos, tendo consentido com a violência (?) por sua vontade, não podia ser ouvida em Juízo ao menos que tivesse sido verdadeiramente forçada. Caso a violada fosse menor de 17 anos, podia em todo caso ser ouvida.

Para por este meio illicito, e criminoso se adquirir Direito ao Matrimonio, ou ao dote: Querendo desde logo occorer a tâo perniciosos abusos, e fraudes: Hei por bem abolir, e extinguir a querella de Estupro, que pela Ordenação do Livro quinto, Titulo vinte e três compete ás mulheres 
virgens, que se deixão corromper por sua vontade. E mando: Primeiro, que nenhuma dellas, excedendo a idade de dezesete anos completos, ainda que tenha contrahido Esponsaes, possa ser ouvida em Juizo, excepto o caso, em que seja real, e verdadeiramente forçada. (...) Porem sendo a corrupta menor dos ditos dezesete anos, attendendo a que a inconsideração, que he ordinaria antes da referida idade para evitar a sua ruina, por isso mesmo agrava o crime do seductor: Ordeno, que ou querellando ella nestes termos, ou seus Pais, Tutores, ou Curadores, seja o seductor condemnado criminalmente nas penas arbitrariasna sobredita fórma, e além dellas no dote, que lhe corresponder, segundo a sua condição, e qualidade, ficando sem vigor as disposiçóes, e penas estabelecidas na referida Ordenação (...). (SILVA, A., 1828, p. 361-363)

Notemos que o estuprador aqui recebe a mesma denominação de "seductor". Falase em crime de estupro, mas chama-se o violador de sedutor. Os conceitos parecem se misturar.

No Brasil colonial, tendo em consideração a aplicação desta mesma legislação portuguesa ao novo território, já vimos uma adaptação do direito lusitano ao contexto brasileiro, como é o caso das Constituiçóes Primeiras do Arcebispado da Baía. Mais, ainda, outras foram declaradas numa tentativa de melhor aplicar o Direito à um realidade completamente diferente de Portugal, como o Alvará Régio de 4 de abril de 1755 que passou a permitir o casamento entre portugueses e índios.

O casamento continuou o centro, e ainda muito reforçado, da administração da sociedade colonial. A necessidade flexibilizou, por uma parte, o direito, como a permissão de casamentos dos portugueses com índias. Mas por outro lado também proibiu, como é o caso da proibição da fundação de mosteiros na nova terra. A dificuldade de encontrar mulheres adequadas aos padróes metropolitanos, aquela branca-europeia-católica-virgem, levou o poder real, dono de um Brasil multicultural pelos próprios artifícios da colonização, a fazer o que fosse preciso para evitar que as poucas restantes ainda fossem tentadas a seguir a vida monástica.

Assim, a Carta Régia de 2 de setembro de 1603 determinou a proibição da fundação de mosteiros de freiras em Pernambuco e na Baía, mas permitiu a fundação de Recolhimentos para donzelas e órfâs, uma vez que estas podiam casar e povoar o Brasil de "gente principal e honrada, que é o intento, com que, do principio do seu descobrimento" (SILVA, J., 1854, p. 22). Em nova Carta régia de 16 de outubro de 1607 (SILVA, J., 1854), novamente foi proibida a fundação de mosteiros, sendo necessário pedir especial autorização ao Rei para suas construçóes. Em Carta Régia de 11 de março de 1620, o rei nega um pedido de Olinda de construir um Mosteiro de Freiras por

"aquella Villa ser porto de mar, e Conquista nova, que tem necessidade de se povoar, se escusará o que pedem - Porém se quiserem fazer um 
Recolhimento de donzelas, para commodidade das filhas dos moradores d`aquelle Estado, que não poderem estar em casa de seus pais, have-lo-hei assim por bem”. (SILVA, J. 1855, p. 6).

Feita essa prévia organização das formalidades do Direito em Portugal e o início de uma adaptação desse ordenamento a uma nova cultura, trazemos dois casos sobre casamento e estupro. Ambos demonstram a proteção da honra e da vergonha (NAZZARI, 2001) acima de qualquer outra qualidade a ser preservada para o importante passo do casamento. Tal sistema exigia que as mulheres solteiras continuassem virgens até a chegada do marido e as casadas fossem fieis a esses maridos e as viúvas, honestas, o que significava não ter mais relaçôes com homens a não ser por novo casamento.

\section{Caso de Josefa Rodrigues Pires da Silva}

O primeiro caso a ser aqui estudado é de sedução e estupro e náo cumprimento da promessa de casamento, relatado num documento de 1765 do Arquivo Histórico Ultramarino (1765) diretamente feito pela suposta vítima. Josefa Rois Pires era filha do capitão José Rodrigues Pires e de Teresa de Andrade Pereira. Vivia sob a companhia e na casa dos pais, recolhida para guardar o seu futuro casamento de acordo com a honra de seus ascendentes, quando Manoel Malheiro de Mello, tenente da infantaria paga da Paraíba, começou a seduzi-la com promessas de casamento, carícias e insinuaçóes. Josefa, cedeu sob a promessa certa de casamento. Ela diz que perdeu a virgindade e honra, e mesmo assim, continuou a se relacionar com ele sob a promessa de se casar.

Entretanto, Manoel Rodrigues anunciou o casamento com outra moça, Anna Escolástica Portela. Josefa, durante os banhos da anunciação do casamento, apresentou impedimento e querelou dele por estupro no Juízo da Ouvidoria Geral da Paraíba.

Entretanto, o suplicado recebeu sentença favorável, pelo que Josefa apelou para a Relação do estado da cidade da Paraíba. Entre suas prisôes e solturas, por fim, foi condenado a casar com Josefa se ela o quisesse ou pagar 4 mil cruzados para seu dote. O dote, como se vê, continuava a chave para uma vida de sucesso de uma filha de um capitão. Recorrendo com embargos, conseguiu diminuir o valor para dois mil cruzados. O muito interessante é que após pedir novamente revisão do valor da condenação, Manuel e Anna foram até a Igreja matriz e, simplesmente, "ahi se cazarão clandetinamente contra a constituiçao, e ley deste Reyno, e sem procederem as denunciaçôes necessarias na forma do sagrado Concilio tridentino, como consta da certidão do escrivão do Juízo Eclesiastico” (ARQUIVO HISTÓRICO ULTAMARINO, 1765, fólio 2).

A documentação em estudo menciona expressamente a necessidade e absurdo de não se ter procedido as denunciaçóes proclamadas pelo Concílio, o que mostra que na Colônia as repercussóes do Encontro de Trento foram formalmente respeitadas e exigidas. 
"Os cazamentos clandestinos alem de serem prohibidos por direyto canonico e civil a nossa ley sinodal constante nunca os defende". Esse casamento simplesmente aconteceu quando o vigário estava no ofertório e entraram na Igreja Manuel e Anna e disseram em voz alta que recebiam um ao outro como legítimos esposos como manda a Santa Madre Igreja. Assim diz a certidão passada pelo escrivão do crime civil como teor da sentença de Manuel que

do referido se mostra haverem contrahido matrimonio clandestino o qual se fizera logo publico na dita cidade causando notável escândalo aos moradores nella, e que a dita Josefa Pires havia provado Esponsais neste juízo contra o Reo e que também dele tinha querellado por estupro na Ouvidoria daquela comarca cuja cauza tendo apelado para a Rellaçam do Estado fora o Reo condenado a que cazase com a dita Jozefa Pires ou que a dotace em quatro mil cruzados (...).

O documento traz ricas informaçôes sobre a condição do casamento, as promessas e a caracterizaçáo do estupro que acusa Josefa, apesar de confessar que consentiu no ato. O consentimento não é enfatizado para caracterizar o estupro alegado, mesmo porque ela confirma que consentiu. Notemos que apenas em 6 de outubro de 1784 houve lei acerca da presunção do estupro para mulheres abaixo dos 17 anos e a possibilidade de serem ouvidas em Juízo.

No primeiro documento a seduçáo leva a denunciação do suplicado por estupro, mostrando a semelhança dos termos. A querela foi feita no Juízo da Ouvidoria Geral da Cidade da Paraíba. A querela era uma ação particular, privada, diferente da devassa.

Toda a configuração do caso levada a Juízo nos remete para elementos essenciais discutidos na legislação acerca da validade e caracterização do matrimônio. José quando tenta casar com Anna pela primeira vez prepara os banhos, os esponsais, e nesse período Josefa anuncia o impedimento. Tal impedimento pode ser visto, e feita as devidas mençóes na obra ao Concílio de Trento, nas Constituiçóes Primeiras do Arcebispado da Baía, no título LXVII: "Impedimentos que só impedem o matrimónio: (...) 2. Esponsaes: convém a saber, se os contrahentes, ou algum delles tem promettido, ou jurado de casar com outra pessoa. (VIDE, 1853, p. 119)".

Para complicar ainda mais a relação, Manoel e Anna eram parentes em quarto grau de consanguinidade e sabiam e incorreram no crime mesmo assim. Em certidáo que foi anexada ao pedido de Josefa, mostra-se que eles foram excomungados, "Excomunham mayor e condemnados em cem cruzados cada hum e em dous annos de degredo para fora do Bispado da Baía i de mais em sincoenta cruzados por saberem estavam ligados com impedimento (...)"

A disposição da decisão se coaduna com que o que encontramos nas Constituições Primeiras do Arcebispado da Baía, posto que aquele 
(...) que casar por palavras de presente com a pessoa, com a qual esteja dentro do quarto grão de conseguinidade, ou affinidade, sabendo do tal impedimento, (alem do Matrimonio ser nullo, e se haverem de separar) fique incorrendo em sentença de excommunhão maior, e será preso no aljube, e conmdenado em cincoenta cruzados, e nas mais penas, que parecerem justas. (VIDE, 1853, p. 122).

Para finalizar, Josefa constata que Manuel não tinha bens que chegassem para suportar o pagamento do seu dote. Como solução, ela solicita ao rei que o Capitáo mor que o soltou da prisão indevidamente também fosse condenado ao pagamento da parte do seu dote que os bens de Manoel não chegassem, uma vez que se estivesse preso não teria se casado com Anna. Ainda reforça outro pedido de prisão de Manuel até que ele pague o seu dote, mediante busca e apreensão dos bens dele. Caso não fossem suficientes, que os bens do Capitão mor que o soltou indevidamente da prisão fossem usados no complemento.

\section{Caso de Teresa Maria do Espírito Santo}

No dia 10 de março de 1769, António de Melo Moniz, Alferes de Infantaria paga da fortaleza de Cabedelo, escreveu carta ao rei D. José I relatando um crime ocorrido contra uma sua filha donzela (ARQUIVO HISTÓRICO ULTAMARINO, 1769).

No primeiro documento na cronologia dos cinco que possuímos no Arquivo Histórico Ultramarino o nome da filha não é citado e a petição foi feita por seu pai. A carta conta o fato. A donzela estava em casa com a mãe e irmãs, recolhida na cama quando José Pinto Coelho, secretário do governo da Paraíba, entrou na casa do Alferes com mais dois homens disfarçados e raptou-a. A mãe, notando a ação criminosa, gritou em voz alta usando o nome do rei e veio socorrê-la o próprio marido e o governador que mandou prender o secretário e chamar o juiz ordinário para conhecer do caso. A carta do alferes diz que a esposa de António gritou em altas vozes para que todos soubessem da sua reprovação daquele ato, tudo feito conforme as ordenaçôes indicavam sobre bradar alto contra os atos do agressor.

$\mathrm{O}$ juiz mandou inquirir as testemunhas que disseram que nada sabiam. Segundo António, silenciaram para não contrariar o governador. Assim, o juiz mandou logo soltar o secretário e mandou fazer um sumário contra o próprio António por usar pistola e faca de ponta, para que sofresse desonra ou acabasse numa cadeia. António relata que foi humilhado e teve que assinar um termo para não ficar "de todo perdido". Descreditado, assim, escreveu ao Rei pedindo justiça. O caso começa desde já levantando muitos questionamentos acerca dos relacionamentos políticos do alferes, do governador e do secretário, uma vez que até faz menção a "outros escândalos que acontecem na Capitania”.

Este caso é bastante rico em vários aspectos. Entre os documentos do Arquivo Histórico Ultramarino ainda há mais quatro documentos acerca deste fato, como dissemos, 
que mostram as outras versóes e a continuação do relatado pelo Alferes. Nove anos depois, em 14 de março de 1778, já no reinado da rainha D. Maria I, António relata novamente o ocorrido, acrescentando novas informaçóes e atualizaçóes (ARQUIVO HISTÓRICO ULTAMARINO, 1778). Ele começa por se identificar e a lembrar no documento que é "huma das pessoas mais principais desta Cappitania da barra da Parahiba", o que com certeza devemos ter em consideração, pois sua posição deve ter contribuído nas possibilidades de reclamar esse tipo de crime, principalmente de se dirigir diretamente à rainha. Ele tinha 6 filhas e vivia com elas e a mulher no Presídio da Fortaleza de Santa Catarina, fortificação ainda imponente até hoje na cidade de Cabedelo. O governador da capitania, José de Mello e Castro, e seu secretário, o citado José Pinto Coelho, faziam frequentes viagens ao dito presídio, quando o secretário iniciou uma amizade com o Alferes e com uma de suas filhas, Thereza. Percebendo das intençôes, o pai tentou afastá-lo da filha para melhor guardar sua honra. Não satisfeito, José Pinto esperou o momento oportuno em que o Alferes estivesse trabalhando e foi com quatro homens armados com catanas e ele com faca de ponta e uma pistola, por volta das 10 horas da noite, e abriu violentamente as portas e raptou Thereza para estuprar sua honra e virgindade contra a vontade de suas filhas, que gritavam no momento juntamente com a mãe por Justiça, clamando em altas vozes. O desfecho do ato foi o envio de Thereza para um Recolhimento na cidade, onde ficou recolhida, até o momento da escrita do documento, que já fazia de sete para oito anos, onde estava desamparada. Nem as reclamaçóes ao Conde de Povolide solucionaram o problema da filha desonrada e do pai humilhado. Por isso, por fim, ele solicitava que sua filha fosse casada e dotada à custa da fazenda de José Pinto.

O terceiro documento encontrado no Arquivo Histórico Ultramarino (1779) está datado de 26 de fevereiro de 1779, ano seguinte do último que analisamos. Dez anos após o ocorrido, Thereza ainda continuava no Recolhimento. O Ofício continua a relatar os abusos cometidos por José Pinto, O documento, desta vez, é do governador da Paraíba, que traz outra perspectiva do acontecido. Apesar da confusão das intrigas entre o alferes, o governador e seu secretário, uma frase chama a atenção, que deixa o leitor afastado do caso pelo tempo e sob a limitação da linguagem ao menos confuso: o governador diz da "sem razam da intempestiva queixa depois de estar o queixozo em amizade com os culpados e ter tido na propia caza a filha que dis raptada”.

Noutro documento, temos um requerimento da própria vítima endereçada à rainha, D. Maria I, de 18 de agosto de 1780 (ARQUIVO HISTÓRICO ULTAMARINO, 1780). Pela primeira vez, 10 anos após o rapto, encontramos um documento assinado por ela. Nele, ela conta como ele insistiu em solicitar dela "amores por si" ao que ela cedeu, pela fraqueza de seu sexo. Thereza cedeu e foi despojada de sua honra e virgindade em uma das visitas que ele lhe fazia no meio das noites. Seu pai, desconfiado, aumentou o controle, mas não serviu para impedir o rapto. Durante o rapto ela confirma os brados de 
protesto da sua mãe, que fora ameaçada com uma pistola nos peitos. Após o rapto Thereza foi levada para um Canoa que já estava preparada na praia e levada para um recolhimento. Os recolhimentos, como vimos, funcionavam no lugar dos Mosteiros de Freiras, que eram proibidos de se construir. Os recolhimentos acolhiam mulheres que ainda pudessem casar, uma vez que a colônia estimulava o aumento das famílias através do casamento.

Thereza faz uma importante menção à lei de 19 de junho de 1775, já citada e transcrita em parte aqui. Com base nela, a suplicante pede à rainha que o indulto para poder querelar de estupro de José Pinto dispensando o tempo de ano e dia que era requerido, o que foi concedido.

O último documento (ARQUIVO HISTÓRICO ULTAMARINO, 1785) encontrado é o único da mão do José Pinto, acusado. A data: 27 de outubro de 1785, 15 anos depois de decorrido o rapto. Ele defende sua inocência e requer à rainha o seu retorno ao exercício da função de secretário do Governo da Paraíba. Alega que foi acusado injustamente por seus inimigos porque bem servia à Rainha. José Pinto também diz que foi expulso da função pública, perdendo o cargo, por ordem da Rainha quando foi pronunciado pelo crime de rapto. Por fim, percebemos ter havido sentença de livramento do crime de rapto que tinha sido originada por uma devassa tirada por ordem do Conselho Ultramarino e seu nome foi para o rol dos culpados.

Vale, por fim, salientar, que o caso fere, de certo, o livro V, título XVIII, parágrafo $3^{\circ}$ mas não o completa considerando a condição de ambos, pai e raptor. Em ambos os casos, acentua-se como previam as Ordenaçóes, o fundo econômico da querela de honra e virgindade: o mais importante a restituir era o dote afetado pela perda da virgindade. Sem isso, não haveria mais bom casamento.

\section{Conclusões}

Os dois casos estudados claramente referem a duas mulheres de classe superior na colônia, uma filha de Alferes de Infantaria Paga e a outra filha de um Capitão. Isso não pode generalizar os processos e os casos que não chegaram a ser sabidos, por diversas razóes, de tantas outras mulheres estupradas, prometidas e casadoiras em Portugal e na colônia.

A pequena amostra revelou grande riqueza na aplicação do direito. Como é importante perceber que a repercussão das normatizes do Concílio de Trento chegou na colônia brasileira e que também foram aplicadas na capitania da Paraíba, uma das mais antigas e criada ainda no reinado ibérico. Não fica difícil entender, agora, os desdobramentos do reconhecimento da união estável no Brasil (e na Europa) diante de tanta confusão durante séculos acerca das formalidades do casamento e como devemos considerar a vida de um casal e seus efeitos jurídicos e sociais na comunidade. A discussão é alargada ainda mais, hoje em dia, em função da reflexão em torno da qualidade de quem compóe a família, e 
aquilo que nunca apareceu em nenhum ordenação ou outras leis, mas sempre existiu nas cartas de amor, nos romances, nos crimes conhecidos, nas vítimas desaparecidas e nos parentes escondidos. $\mathrm{O}$ que não era formalizado no passado vem à tona legitimado ou em sua via: a afirmação das mães solteiras, os irmãos indistintos que herdam, o casal homoafetivo que se casa e adota, do sobrinho e tia que formam uma família.

Os processos demonstram e comprovam o que a literatura e outros importantes estudos citados já vislumbravam: também na Paraíba era importante a virgindade e vigorava o sistema da honra e da vergonha. Casamento podia ser solução para um problema, ou crime, como ainda o era até poucos anos atrás nos Códigos Civil e Penal Brasileiros, por exemplo, quando o casamento entre agressor e agredida nos crimes sexuais podia servir como causa extintiva da punibilidade daquele. Aos poucos, essa glorificação de um modelo de mulher acostumada a ser corrigida, da santa que não saia de casa era (e não diremos apenas) um modelo - a realidade, principalmente a realidade colonial, mostrou a vivacidade e a necessidade de transgressão; de ambos os lados, de ambos os gêneros.

Já estamos tão longe desses processos? Todas as mulheres do mundo veem perfeitamente a vida fora do casamento? Violência doméstica é um assunto privado, que não pode ser tratado via ação penal pública incondicionada? O estupro é uma realidade distante, improvável de acontecer quando as mulheres estão a passear pelas ruas à noite, com pouca roupa numa calma noite de verão? Estamos livre de caracterizar o crime sexual para além das qualidades da vítima, como mostraram os processos dessas mulheres de conduta exemplar, de vida honesta e casta, debaixo da guarda dos pais honrados e que tinham tido uma exclusiva, única relação com o agressor-acusado? Receamos, com felicidade, acabar com mais questôes do que as certezas perigosas que a pesquisa histórica pode nos oferecer.

\section{Referências}

BUTLER, Judith. Gender Trouble. New York and London: Routledge, 2010.

CAETANO, Marcelo. História do Direito Português (Sécs. XII - XVI). Lisboa/São Paulo: Verbo, 2000.

CABRAL, Antonio Vanguerve. Epilogo Juridico de Varios Casos Civeis, e Crimes Concernentes ao Especulativo, \& Pratico Controvertidos, disputados e Decididos a Mayor Parte Delles no Supremo Tribunal da Corte, \& Casa da Supplicaçáo com Humas Infignes Annotaçoens à Ley Novissima da Prohibiçáo das Facas, \& mais Armas Promulgada em 4 de Abril de 1719. Lisboa Occidental: Na Officina de Antonio Pedroso Galram, 1729.

CASTRO, José de. Portugal no Concilio de Trento. Lisboa: Uniao Grafica, 1944.

COLLECÇÃO CHRONOLOGICA DOS ASSENTOS DAS CASAS DA SUPPLICA-

ÇÃO E DO CIVEL. Coimbra: Real Imprensa da Universidade, 1791. 
FIGUEIREDO, José Anastasio de. Synopsis chronologica de subsidios ainda os mais raros para a historia e estudo critico da Legislação Portuguesa. Lisboa: Officina da Academia Real das Sciencias, 1790.

GILISSEN, John. Introdução Histórica ao Direito. 5. ed. Lisboa: Fundação Calouste Gulbenkian, 2008.

GUIMARÃES, José Jorge Alves. A Evolução das Normas Constitucionais sobre o Casamento nos Arcebispados de Braga e da Baía (1505-1719). In: SILVA, Maria Beatriz Nizza da. Sexualidade, família e religiáo na colonizaçáo do Brasil. Lisboa: Livros Horizonte, 2001.

HERCULANO, Alexandre. Estudos sobre o casamento civil. Lisboa: Antiga Casa Betrand - José Bastos \& $\mathrm{C}^{\mathrm{a}}$. Editores, 1866.

LEAO, Duarte Nunes de. Leis extrauagantes / collegidas e relatadas pelo licenciado Duarte Nunez do Liam per mandado do muito alto \& muito poderoso Rei Dom Sebastiam nosso Senhor. Lisboa, per Antonio Gonçaluez, 1569.

MEADOW, Tey. A Rose is a Rose. On producing Legal Gender Classifications. Gender and Society, v. 24, n. 6, p. $814-837$, dec. 2010.

MEREAA, Paulo. Em Torno do Casamento de Juras. In: Estudos de Direito Hispânico Medieval. Coimbra: Acta Universitatis Conimbrigensis, 1952, tomo I.

MONCADA, Luís Cabral de Oliveira. O Casamento em Portugal na Idade Média. Estudos de História do Direito. Coimbra: Acta Universitatis Conimbrigensis, 1948, vol I.

NAZZARI, Muriel. Sem Perda da Honra: a preservaçãoo da reputaçãoo feminina no Brasil colonial. In: SILVA, Maria Beatriz Nizza da. Sexualidade, família e religiáo na colonizaçáo do Brasil. Lisboa: Livros Horizonte, 2001.

PORTUGAL. Arquivo Histórico Ultramarino. Carta do alferes de Infantaria paga da guarnição da fortaleza do Cabedelo, António de Melo Moniz, ao rei [D. José I], denunciando os actos do secretário do governo da Paraíba, José Pinto Coelho, que raptou sua filha; e os procedimentos do governador, que mandou soltar o secretário da prisão, ordenando ao juiz que fizesse um sumário contra ele. Paraíba, 10 de março de 1769, AHU_CU_014, Cx. 24, D. 1852.

PORTUGAL. Arquivo Histórico Ultramarino. Requerimento de Josefa Rodrigues Pires Silva, filha do capitão José Rodrigues Pires e Teresa de Andrade Pereira, ao rei [D. José I], solicitando que se mande recolher à cadeia o tenente de Infantaria da Paraíba, Manuel Malheiros de Melo, e que dela não seja solto enquanto não satisfazer inteiramente o seu dote, por culpa de sedução e estupro, e casamento clandestino com Ana Escolástica Portela. Paraíba, 5 de setembro de 1765, AHU_CU_014, Cx. 23, D. 1765 . 
PORTUGAL. Arquivo Histórico Ultramarino. Requerimento de Teresa Maria do Espírito Santo, filha do alferes de Infantaria da guarnição da fortaleza do Cabedelo, à rainha [D. Maria I], solicitando que se faça devassa contra o secretário do governador da Paraíba,[José Pinto Coelho], pelo crime de estupro e rapto. Paraíba, 18 de agosto de 1780, AHU_CU_014, Cx. 27, D. 2071.

PORTUGAL. Arquivo Histórico Ultramarino. Requerimento do alferes de Infantaria paga da guarnição da fortaleza do Cabedelo, António de Melo Moniz, à rainha [D. Maria I], solicitando que José Pinto Coelho seja punido pelo seqüestro e estupro da sua filha. Paraíba, 14 de março de 1778, AHU_CU_014, Cx. 26, D. 2001.

PORTUGAL. Arquivo Histórico Ultramarino. Requerimento do bacharel José Pinto Coelho, à rainha [D. Maria I], solicitando mandar que o suplicante possa reassumir o ofício de secretário do governo da Paraíba, visto ser inocente da acusação do crime de rapto. Paraíba, 27 de outubro de 1785, AHU_CU_014, Cx. 29, D. 2146.

PORTUGAL. Arquivo Histórico Ultramarino. Ofício do [governador da Paraíba], brigadeiro Jerónimo José de Melo e Castro, ao [secretário de estado da Marinha e Ultramar], Martinho de Melo e Castro, informando que o alferes António de Melo Moniz conseguiu uma provisão do Conselho Ultramarino para devassar o caso do rapto da filha, sendo pronunciado o seu secretário de governo. Paraíba, 26 de fevereiro de 1779, AHU_CU_014, Cx. 26, D. 2035.

PORTUGAL. Código Filipino ou Ordenaçóes e Leis do Reino de Portugal. Livro II. Reprodução «fac-simile» da 14 a edição de 1870, com introdução e comentários de Cândido Mendes de Almeida. Brasília: Senado, 2004.

PORTUGAL. Código Filipino ou Ordenaçóes e Leis do Reino de Portugal. Livro IV. Reprodução «fac-simile» da 14 a edição de 1870, com introdução e comentários de Cândido Mendes de Almeida. Brasília: Senado, 2004.

PORTUGAL. Código Filipino ou Ordenaçóes e Leis do Reino de Portugal. Livro V. Reprodução «fac-simile» da 14 a edição de 1870, com introdução e comentários de Cândido Mendes de Almeida. Brasília: Senado, 2004.

PORTUGAL. Ordenaçóes Manuelinas. Livro II. Reprodução «fac-simile» da edição de 1797. Coimbra: Fundação Calouste Gulbenkian, 2006.

PORTUGAL. Ordenações de D. Duarte. Edição preparada por Martim de Albuquerque e Eduardo Borges Nunes (Lisboa 1988).

SCLIAR, Moacyr. Saturno nos Trópicos: a melancolia europeia chega ao Brasil. São Paulo: Companhia das Letras, 2003.

SILVA, António Delgado da. Collecçáo da Legislação Portugueza desde a última Compilação das Ordenaçóes - 1775 a 1790. Lisboa: Typografia Maigrense, 1828. 
SILVA, José Justino de Andrade. Collecção Chronologica da Legislação Portugueza 1603 - 1612. Lisboa: Imprensa de F. X. de Souza, 1854.

SILVA, José Justino de Andrade. Collecção Chronologica da Legislaçáo Portugueza 1620 - 1627. Lisboa: Imprensa de F. X. de Souza, 1855.

SILVA, José Justino de Andrade. Collecção Chronologica da Legislaçáo Portugueza 1648 - 1656. Lisboa: Imprensa de F. X. de Souza, 1856.

VIDE, Sebastião Monteiro da. Constituiçóes Primeiras do Arcebispado da Baía. São Paulo: Typographia 2 de Dezembro de Antonio Louzada de Antunes, 1853. 